\title{
Microwave-Assisted Synthesis of Andrographolide Analogues as Potent $\beta$-Glycosidase Inhibitors
}

\author{
Masood ur Rahmana,b \\ Iram Ayoobc \\ Shakeel u Rehmanc \\ Khursheed A. Bhat ${ }^{b}$ \\ Tabassum Ara*a \\ ${ }^{a}$ Organic Chemistry Research Lab, Department of Chemistry, \\ National Institute of Technology, Srinagar, 190006, India \\ b Bioorganic Chemistry Division, IIIM, Sanatnagar, Srinagar, \\ 190005, India \\ Department of Chemistry, University of Kashmir, Srinagar, \\ 190006, India
}
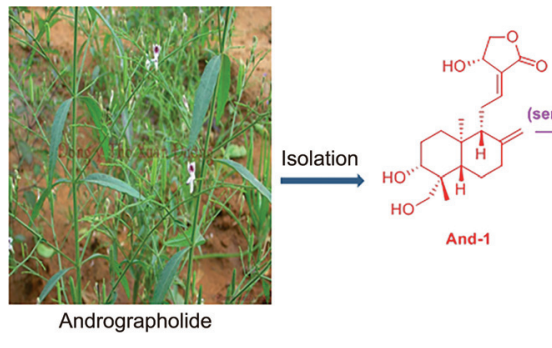

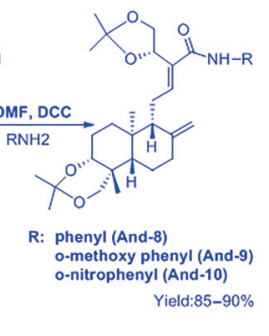

Received: 31.12.2017

Accepted after revision: 04.03.2018

Published online: 13.06 .2018

DOI: 10.1055/s-0036-1591967; Art ID: so-2017-d0064-op

License terms: cc)

Abstract Andrographolide, a bioactive compound isolated from Andrographis paniculata exhibits multiple pharmacological activities, including anti-HIV, antiplatelet aggregation, hepatic lipid peroxidation protective, hepatoprotective, choleretic, and anticancer effects. Herein, we report the synthesis of diverse analogues of andrographolide along with their $\beta$-glucosidase inhibitory activity against sweet almond $\beta$-glucosidase. The parent compound, And-1, displayed moderate inhibitory activity against the sweet almond $\beta$-glucosidase with $I_{50}$ of $142.5 \mu \mathrm{M}$. Among the synthesised analogues And-10 showed the best activity, with $\mathrm{IC}_{50}$ of $92.4 \mu \mathrm{M}$, whereas the oxidised products (And-4 and And-5) were moderately active against the tested enzyme. Additionally, compounds And-6, And-7, And-8, and And-10 exhibited better $\beta$-glucosidase inhibitory activity than the positive control Castanospermine, with $I_{50}$ of $100.2,102.4,106.5$, and $92.4 \mu \mathrm{M}$, respectively. These results highlight the importance of an electron-withdrawing $\mathrm{NO}_{2}$ group on the phenyl moiety in attaining the better $\beta$-glucosidase inhibition. It is noteworthy that the effect of a particular group plays a significant role in bioactivity. This study thus highlights an important aspect with regard to the most active compounds, which could extend the arsenal of compounds affecting the corresponding enzymes after further polishing and fine tuning.

Key words andrographolide, $\beta$-glucosidase, sweet almond, Castanospermine

\section{Introduction}

Andrographis paniculata (family: Acanthaceae) is a wellknown medicinal plant that is commonly known as the king of bitters because of its extremely bitter taste. It is a perennial herb that is widely distributed and cultivated in India, Pakistan, China, and Sri-Lanka. It also grows in many other Asian countries and is used as a traditional herbal medicine in China, Hong Kong, Philippines, Malaysia, Indo- nesia, and Thailand. ${ }^{1}$ As an Ayurvedic herb, it is known as Kalmegh or Kalamegha, meaning 'dark cloud'. A. paniculata is one of the most commonly used medicinal plants in the traditional systems of Unani and Ayurvedic medicines. ${ }^{1}$ A. paniculata is reported to exhibit a broad range of pharmacological effects such as immunostimulant, ${ }^{2}$ antimicrobial, ${ }^{3}$ anti-inflammatory, ${ }^{4}$ hypotensive, ${ }^{5}$ antihyperglycemic, ${ }^{6,7}$ atherosclerotic, ${ }^{8}$ antimalarial, ${ }^{9}$ anti-HIV, ${ }^{10}$ antiplatelet aggregation, ${ }^{11}$ hepatic lipid peroxidation protective, ${ }^{12}$ hepatoprotective, ${ }^{13}$ choleretic, ${ }^{14}$ and anticancer effects. ${ }^{15-17}$

Andrographolide is the major labdane diterpenoid isolated from A. paniculata and exhibits both in vitro as well in vivo anti-inflammatory and anticancer activities. The effects of andrographolide on leukocyte (neutrophils, macrophages and T-cells) and endothelial cells demonstrate the ability of this compound to reduce the level of expression and production of proinflammatory mediators. Several in vitro studies revealed that andrographolide helps to reduce the output of oxygen radical superoxide anion and hydrogen peroxide, as well as the adhesion induced by chemo-attractant in isolated neutrophils. ${ }^{18,19}$ Andrographolide is reported to reduce the activation of human and murine Tcells, T-cells proliferation, interleukin-2 (IL-2) and IFNY production ${ }^{20-23}$ and it is also reported to reduce endothelial cell proliferation, migration and invasion, thereby implying its function in angiogenesis. ${ }^{24}$ In addition, andrographolide reduces the growth factor deprivation induced apoptosis in endothelial cells. ${ }^{25}$ Moreover andrographolide also exerts antiproliferative and pro-apoptotic effects in RAFLSs, with $\mathrm{G}_{0} / \mathrm{G}_{1}$ cell cycle arrest, amplifies the expression of cell-cycle inhibitors p21 and p27 and reduces cyclin-dependent kinase $4 .^{26}$

Glycosidase inhibitors are of particular interest in the development of potential pharmaceuticals such as antitumor, ${ }^{27-29}$ antiviral, ${ }^{30,31}$ antidiabetics, ${ }^{32-45}$ and immunoregulatory agents. ${ }^{36}$ The ethanolic extract of A. paniculata dis- 
plays antidiabetic properties. ${ }^{37,38}$ Significant decline in the level of blood glucose was recorded when hyperglycaemic rats were treated with aqueous extract of $A$. paniculata. ${ }^{39}$ Therefore, it will be interesting to investigate the inhibitory activities of andrographolide and its analogues against glucosidases. The extracts of A. paniculata are known to contain diterpenes, flavonoids, and stigmasterols. ${ }^{40}$ Diterpenes from A. paniculata, like andrographolide, contain three hydroxyls, an a-alkylidene c-butyrolactone moiety and two fused six-membered rings. Both the six-membered rings adopt the chair conformation, whereas the five-membered ring is in an envelope conformation. ${ }^{41}$ They were found to be structurally similar to some known glycosidase inhibitors to some extent. ${ }^{42,43}$ However, there are limited reports about activities of the extracts or constituents of $A$. paniculata against $\beta$-glucosidases.

A few important glycosidase inhibitors that are already on the market as drugs include acarbose (a tetrasaccharide with a carbamino sugar moiety), miglitol or Glysett ${ }^{\mathrm{TM}}$ (aminosugar), which is an analogue of 1-deoxynojirimycin, and voglibose (a carbamino sugar) against type II diabetes; Tamiflu $^{\mathrm{TM}}$ or oseltamivir (a carbamino sugar) (Figure 1) is an antiviral drug used against Swine flu and is a neuraminidase inhibitor. Besides these, Zavesca ${ }^{\mathrm{TM}}$ or miglustat is used for the treatment of Gaucher's disease, which is a severe lysosomal storage disorder, as it is an inhibitor of glucosylceramide synthase, a glycosyl transferase. There are a few naturally occurring bridged molecules, known as nortropanes, which are also excellent glycosidase inhibitors. ${ }^{44}$ However, most of the synthetic glucosidase inhibitors; acarbose, miglitol voglibose, and castanospermine prescribed for the treatment of type 2 diabetes, and viral diseases have certain adverse effects such as hypoglycemia at higher doses, liver problems, lactic acidosis and diarrhoea. ${ }^{45,46}$

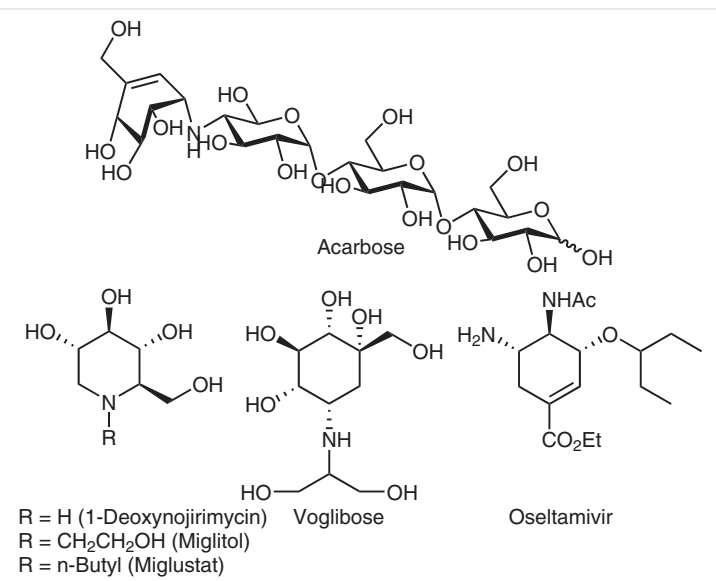

Figure 1 Commercially available glycosidase inhibitors

Given these important developments related to the utility of the glycosidase inhibitors described above, we developed a random combinatorial library of andrographolide to test its glycosidase potential. Since the extracts of A.paniculata and the isolated constituents have been reported to possess a wide spectrum of biological activities. In recent years, besides the above bioactivities, the antidiabetic effect of the plant has attracted the attention of researchers. Therefore, it is of immense interest to investigate the inhibitory activity of the major constituent andrographolide and its derivatives against glycosidase. Although the $\alpha$-glycosidase inhibitory activity of andrographolide and its derivatives is widely studied, we investigated its $\beta$-glycosidase inhibitory potential.

\section{Results and Discussion}

\section{Chemistry}

Andrographolide, a labdane diterpene, was isolated in good yield $(0.6 \%)$ from the leaves of $A$. paniculata. In view of the interesting pharmacological potential of labdane diterpenes in general and andrographolide (And-1) in particular, a series of different androgapholide analogues (And-2 to And-10) was prepared with microwave assistance in good to excellent yields to assess their $\beta$-glycosidase inhibitory potential. Glycosyl transfer reactions are of prime importance in pharmacology and are therefore essential targets for model catalyst research in the field of diabetes and cancer etc. In the present study, andrographolide (And-1) was taken as starting material and the hydroxyl groups were protected at C-3 and C-19 using 2,2-dimethoxypropane in the presence of para-toluene sulfonic acid ( $p$-TSA) in acetone to furnish its acetonide (3,19-isopropylideneandrographolide), And-2 (Scheme 1). Since this pair of hydroxyl groups (C-3 and C-19) are in the same orientation, it becomes easy to protect them, leaving only one hydroxyl group free. The structure of And-2 was determined based on spectral data analysis ( ${ }^{1} \mathrm{H}$ and ${ }^{13} \mathrm{C}$ NMR) and ESI-MS $(\mathrm{m} / z$ 376.22). In another reaction, And-1 was allowed to react with $\mathrm{Al}_{2} \mathrm{O}_{3}$ in pyridine and toluene for three minutes to yield its dehydrated product And-3 (dehydroandrographolide) in almost 95\% yield. The conjugated olefinic protons were detected at $\delta=6.79$ and $6.15 \mathrm{ppm}$. Based on the coupling constant $J_{\mathrm{H} 11, \mathrm{H} 12}(15.9 \mathrm{~Hz})$, the conformation of the double bond was confirmed to be $E$. And-3 was subjected to oxidation at the two hydroxyls using PCC in $\mathrm{CH}_{2} \mathrm{Cl}_{2}$ to yield And-4 (50\%) and And-5 (30\%). In another reaction, And-1 was hydrolyzed using $1 \mathrm{~N} \mathrm{NaOH}$ to yield the lactone ringopened product (And-6) in 80\% yield. And-6 was further protected at four free hydroxyls using 2,2-dimethoxypropane in the presence of $p$-TSA in acetone, yielding its diacetonide (And-7) with a free acid moiety. And-7 was treated with three different anilines in the presence of EDCI to give the corresponding amides (And-8, And-9 and And-10) in 
<smiles>C=C1CC[C@@H]2[C@@H](CCC(=O)[C@H](C)[C@@H]2C)[C]1/C=C/C1=CCOC1=O</smiles><smiles>C=C1CC[C@]2(C)[C@@H](CC[C@@H](O)[C@@]2(C)CO)[C@@H]1/C=C/C1=CCOC1=O</smiles>

(D)

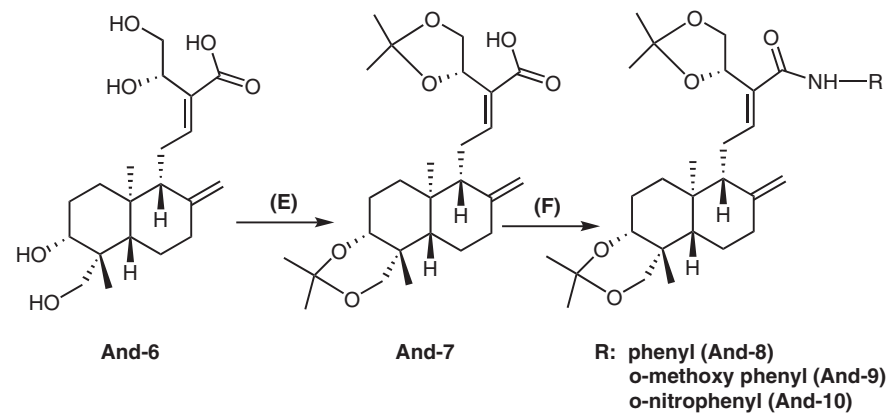

Scheme 1 Reagents and conditions: (A) PTSA (cat.), 2,2-dimethoxy propane, acetone, 95\%; (B) Pyridine, $\mathrm{Al}_{2} \mathrm{O}_{3}$, toluene, $92 \%$; $(\mathrm{C}) \mathrm{CH}_{2} \mathrm{Cl}$, $\mathrm{PCC}$, r.t.; (D) Acetone, aq. $1 \mathrm{~N} \mathrm{NaOH}, 1$ min, 85\%; (E) PTSA (cat.), 2,2-dimethoxy propane, acetone, 3 min, 80\%; (E) DMF, DCC, R-NH $2,85-90 \%$

excellent yields. The structures of all the analogues were determined based on spectral data analysis $\left({ }^{1} \mathrm{H}\right.$ and ${ }^{13} \mathrm{C}$ NMR) and ESI-MS in the light of literature.

\section{Biology}

\section{Glucosidase Inhibition Studies}

Glycosidases are carbohydrate processing enzymes that are implicated in an array of vital biological processes that include cell-cell and cell-virus recognition, synthesis of complex carbohydrates, $\mathrm{N}$-linked glycoprotein processing etc. Inhibitors of such enzymes, both natural and synthetic, have been the subject of extensive studies in the past few decades. Such inhibitors have been found to have tremendous potential as therapeutic agents in the treatment of a number of diseases such as diabetes, obesity, high blood pressure, viral infection, lysosomal storage disorder, tu- mour metastasis etc. ${ }^{47}$ There is no doubt that many more glycosidase inhibitors of practical use remain to be discovered. In view of the early reports of $\alpha$-glucosidase inhibition by andrographolide derivatives and the necessity to develop new glycosidase inhibitors, in the present work we aimed to evaluate the possible $\beta$-glucosidase inhibitory activity of different derivatives of andrographolide.

Preliminary screening of the derivatives was carried out at $166.7 \mu \mathrm{M}$ concentration and percent glucosidase inhibition was determined. The inhibitory effects of all the synthesised derivatives were compared with those of castanospermine, a well-known and potent $\beta$-glycosidase inhibitor. ${ }^{47}$ The analogues that exhibited significant $\beta$-glucosidase inhibition $(>50 \%)$ at the preliminary screening concentration were further assayed at different concentrations (16.6, $41.5,83.3,166.7$, and $250.0 \mu \mathrm{M}$ ) to generate the $\mathrm{IC}_{50}$ values (Table 1 ). The values are the average of triplicate analysis. 
Table $1 \quad I C_{50}(\mu \mathrm{M})$ Values of Andrographolide Analogues against Sweet Almond $\beta$-Glucosidase

\begin{tabular}{lll}
\hline Entry & Substrate & $\mathrm{IC}_{50}$ \\
\hline 1 & And-1 & $142.5 \pm 1.20$ \\
2 & And-2 & $116.5 \pm 1.04$ \\
3 & And-3 & $152.6 \pm 2.12$ \\
4 & And-4 & $178.8 \pm 1.72$ \\
5 & And-5 & $172.6 \pm 1.25$ \\
6 & And-6 & $100.2 \pm 1.52$ \\
7 & And-7 & $102.4 \pm 1.39$ \\
8 & And-8 & $106.5 \pm 1.82$ \\
9 & And-9 & $128.9 \pm 2.01$ \\
10 & And-10 & $92.4 \pm 1.02$ \\
11 & Castanospermine & $108.6 \pm 1.12$ \\
\hline
\end{tabular}

All the synthesised analogues exhibited moderate to appreciable enzyme inhibition against sweet almond $\beta$-glucosidase. The parent compound, And-1, displayed moderate inhibitory activity against sweet almond $\beta$-glucosidase, with $\mathrm{IC}_{50}$ of $142.5 \mu \mathrm{M}$. Among the synthesised analogues, And-10 showed the best activity, with $\mathrm{IC}_{50}$ of $92.4 \mu \mathrm{M}$, whereas as the oxidised products And-4 and And-5 were moderately active against the tested enzyme. Additionally, compounds And-6, And-7, And-8, and And-10 exhibited better $\beta$-glucosidase inhibitory activity than the positive control Castanospermine, with $\mathrm{IC}_{50}$ of $100.2,102.4,106.5$, and $92.4 \mu \mathrm{M}$, respectively.

The activity profile reflects the conclusion that the compound with $-\mathrm{OH}$ protected product (And-2) exhibited slightly better activity than the parent molecule (And-1). The dehydrated product, And-3 (dehydroandrographolide) exhibited poorer activity than And-1, whereas its oxidised products And-4 and And-5 were even less active than And3 , reflecting the importance of the $\mathrm{OH}$ groups for their $\beta$ glucosidase inhibition. The lactone ring-opened product (And-6) exhibited superior potency to castanospermine (positive control); we therefore prepared further derivatives of And-6 to check their $\beta$-glucosidase inhibitory activity. And-6 was protected at the four $\mathrm{OH}$ groups, leaving the only $\mathrm{COOH}$ functionality free (And-7). Among the synthesised amides of the protected derivative, And-10, with a 0 nitrophenyl moiety, exhibited the best activity $\left(\mathrm{IC}_{50}\right.$ of 92.4 $\mu \mathrm{M}$ ), whereas And-8, with a phenyl moiety, exhibited similar activity to that of And-7. And-9, with a 0 -methoxyphenyl moiety, exhibited less activity than And-7. These results highlight the importance of the electron-withdrawing $\mathrm{NO}_{2}$ group on the phenyl moiety in attaining better $\beta$-glucosidase inhibition. It is noteworthy that the effect of a particular group plays a significant role in bioactivity. The most ac- tive compounds could extend the arsenal of compounds affecting the corresponding enzymes after further polishing and fine tuning.

\section{Conclusion}

In this initial report we have summarised the evaluation of $\beta$-glucosidase inhibitory activity of andrographolide analogues synthesised by using a microwave-assisted route. The structures of the compounds were determined based on spectral data analysis in the light of literature. Most of the products exhibit exceptionally good $\beta$-glucosidase inhibitory activity. And-10, And-6, And-7, and And-8 exhibited superior potency to castanospermine, with $\mathrm{IC}_{50}$ of 92.4 , $100.2,102.4$, and $106.5 \mu \mathrm{M}$, respectively. Such molecules would be useful for the development of new drugs such as antidiabetics and antitumour compounds etc. However, further studies especially in vivo studies need to be carried out to reveal the exact mechanism of action.

All reagents for chemical synthesis were obtained from Sigma Aldrich and the solvents used in reactions were distilled and dried prior to use. Reactions were carried out in an Anton Paar Monowave 300 Microwave Synthesizer. All the chemical reactions were monitored by TLC on $0.25 \mathrm{~mm}$ silica gel $60 \mathrm{~F}_{254}$ plates (E. Merck) and the spots were visualised at 366 and $254 \mathrm{~nm}$ in a UV chamber. Purification of compounds was carried out by column chromatography using Silica gel 60-120 mesh stationary phase. ${ }^{1} \mathrm{H}$ NMR and ${ }^{13} \mathrm{C}$ NMR spectra (with chemical shifts expressed in ppm and coupling constants in Hertz) were recorded with a Bruker DPX 400 instrument using $\mathrm{CD}_{3} \mathrm{OD}$ and $\mathrm{CDCl}_{3}$ as the solvent with TMS as internal standard. Mass spectra were recorded with an Agilent Technologies 6540 instrument and melting points of compounds were recorded with a Büchi melting point apparatus B-542.

\section{Plant Material}

The aerial parts of $A$. paniculata were collected from a local herb supplier in October 2013, and authenticated by a taxonomist.

\section{Isolation of Andrographolide}

The herb of Andrographis paniculata Ness (2.0 kg) was macerated and extracted with dichloromethane/methanol (1:1). The solvent was concentrated in vacuo to give the extract (190 g). The extract was subjected to silica gel column chromatography and eluted with a gradient of hexane-EtOAc to afford andrographolide (6.8 g). Its spectral data (IR, ${ }^{1} \mathrm{H}$ NMR, ${ }^{13} \mathrm{C}$ NMR and MS) was in accordance with reported data. $^{27}$

\section{Andrographolide (And-1)}

Formula: $\mathrm{C}_{20} \mathrm{H}_{30} \mathrm{O}_{5}$; colourless crystals; $\mathrm{mp} 232{ }^{\circ} \mathrm{C}$.

${ }^{1} \mathrm{H}$ NMR $\left(\mathrm{CD}_{3} \mathrm{OD}, 400 \mathrm{MHz}\right): \delta=6.62(\mathrm{t}, J=4.5 \mathrm{~Hz}, 1 \mathrm{H}), 5.73(\mathrm{~d}, J=$ $8.0 \mathrm{~Hz}, 1 \mathrm{H}), 5.08$ (d, J = 8.0 Hz, $1 \mathrm{H}$ ), 4.91 (br. s, $1 \mathrm{H}), 4.81$ (br. s, $1 \mathrm{H}$ ), 4.63 (br. s, $1 \mathrm{H}), 4.41(\mathrm{~m}, 1 \mathrm{H}), 4.15(\mathrm{~d}, J=10.3 \mathrm{~Hz}, 1 \mathrm{H}), 4.05$ (d, $J=$ $10.9 \mathrm{~Hz}, 1 \mathrm{H}), 3.86(\mathrm{~d}, J=12.0 \mathrm{~Hz}, 1 \mathrm{H}), 3.27(\mathrm{~m}, 1 \mathrm{H}), 2.50(\mathrm{~m}, 3 \mathrm{H})$, $2.32(\mathrm{~d}, J=12.6 \mathrm{~Hz}, 1 \mathrm{H}), 1.93(\mathrm{~m}, 2 \mathrm{H}), 1.68(\mathrm{~m}, 2 \mathrm{H}), 1.37(\mathrm{~m}, 1 \mathrm{H})$, $1.22(\mathrm{~m}, 1 \mathrm{H}), 1.09(\mathrm{~s}, 3 \mathrm{H}), 0.66(\mathrm{~s}, 3 \mathrm{H})$. 
${ }^{13} \mathrm{C}$ NMR $\left(\mathrm{CD}_{3} \mathrm{OD}, 100 \mathrm{MHz}\right): \delta=169.92(\mathrm{C}-16), 147.52(\mathrm{C}-8), 146.29$ (C-12), 128.90 (C-13), 108.22 (C-17), 78.36 (C-3), 74.28 (C-15), 64.43 (C-14), 62.57 (C-19), 55.40 (C-9), 54.27 (C-5), 42.42 (C-4), 38.82 (C10), 36.71 (C-7), 35.82 (C-1), 27.81 (C-2), 23.89 (C-11), 23.00 (C-6), $22.6(\mathrm{C}-18), 14.68(\mathrm{C}-20)$.

ESI-MS: $m / z$ found for $\mathrm{C}_{20} \mathrm{H}_{30} \mathrm{O}_{5}: 351.21[\mathrm{M}+\mathrm{H}]^{+}$.

\section{Synthesis of 3,19-Isopropylidene Andrographolide (And-2)}

And-1 (1.0 g, 1 equiv) was taken in acetone $(5 \mathrm{~mL}), p$-toluene sulfonic acid monohydrate $(0.33 \mathrm{~g}, 0.3$ equiv) and 2,2-dimethoxy propane (1.9 $\mathrm{mL}, 3$ equiv) were added and the mixture was heated in a microwave synthesiser for $2 \mathrm{~min}$ at $100{ }^{\circ} \mathrm{C}$. After completion of the reaction, triethylamine $(1 \mathrm{~mL})$ was added to quench the remaining catalyst and the solvents were removed in vacuo. The residue was subjected to column chromatography using hexane/EtOAc (8:2) as mobile phase to give And-2.

Yield: $1.1 \mathrm{~g}$ (92\%); white crystalline solid; $\mathrm{mp} 194^{\circ} \mathrm{C}$.

${ }^{1} \mathrm{H}$ NMR (400 MHz, $\left.\mathrm{CD}_{3} \mathrm{OD}\right): \delta=6.94(\mathrm{~m}, 1 \mathrm{H}), 4.90(\mathrm{~s}, 1 \mathrm{H}), 4.63(\mathrm{~s}$, $1 \mathrm{H}), 4.44(\mathrm{dd}, J=6.0,10.6 \mathrm{~Hz}, 1 \mathrm{H}), 4.26(\mathrm{dd}, J=2.0,10.6 \mathrm{~Hz}, 1 \mathrm{H}), 3.17$ $(\mathrm{d}, J=11.4 \mathrm{~Hz}, 1 \mathrm{H}), 3.51(\mathrm{dd}, J=3.6,8.6 \mathrm{~Hz}, 1 \mathrm{H}), 3.97(\mathrm{~d}, J=11.4 \mathrm{~Hz}$, $1 \mathrm{H}), 5.02(\mathrm{br} \mathrm{s}, 1 \mathrm{H}), 2.84(\mathrm{~d}, J=7.0 \mathrm{~Hz}, 1 \mathrm{H}), 2.58(\mathrm{~m}, 2 \mathrm{H}), 2.42(\mathrm{~m}$, $1 \mathrm{H}), 1.99(\mathrm{~m}, 1 \mathrm{H}), 1.73-1.88(\mathrm{~m}, 4 \mathrm{H}), 1.25-1.34(\mathrm{~m}, 3 \mathrm{H}), 1.42(\mathrm{~s}$, $3 \mathrm{H}), 1.36$ (s, $3 \mathrm{H}), 1.20(\mathrm{~s}, 3 \mathrm{H}), 0.95(\mathrm{~s}, 3 \mathrm{H})$.

${ }^{13} \mathrm{C}$ NMR (100 MHz, $\left.\mathrm{CD}_{3} \mathrm{OD}\right): \delta=172.5,149.4,148.9,129.7,109.5$, $100.4,77.7,76.1,66.5,64.9,57.3,53.2,39.4,38.9,38.6,35.5,27.3$, 26.4, 26.1, 25.7, 25.6, 24.3, 16.7 .

ESI-MS: $m / z$ found for $\mathrm{C}_{23} \mathrm{H}_{34} \mathrm{O}_{5}: 413.32[\mathrm{M}+\mathrm{Na}]^{+}$.

\section{Synthesis of Dehydroandrographolide (And-3)}

And-1 (1.0 g) was dissolved in anhydrous pyridine $(2.5 \mathrm{~mL})$, and then activated alumina $(0.2 \mathrm{~g})$ was added. The reaction temperature was programmed at $85^{\circ} \mathrm{C}$ in a microwave synthesiser for 3 minutes. After cooling, the whole solution was filtered, washed with chloroform, and evaporated to obtain a residue, which was purified by column chromatography (EtOAc/hexane, 1:1).

Yield: 87\%; white powder.

$\left.{ }^{1} \mathrm{H} \mathrm{NMR} \mathrm{(400} \mathrm{MHz,} \mathrm{CDCl}_{3}\right): \delta=7.14(\mathrm{~s}, 1 \mathrm{H}), 6.84(\mathrm{dd}, J=10.0,16.0 \mathrm{~Hz}$, $1 \mathrm{H}), 6.10(\mathrm{~d}, J=16.0 \mathrm{~Hz}, 1 \mathrm{H}), 4.78(\mathrm{~s}, 2 \mathrm{H}), 4.75(\mathrm{~s}, 1 \mathrm{H}), 4.50(\mathrm{~s}, 1 \mathrm{H})$, $4.17(\mathrm{~d}, J=10.8 \mathrm{~Hz}, 1 \mathrm{H}), 3.43(\mathrm{~m}, 1 \mathrm{H}), 3.32(\mathrm{~d}, J=10.8 \mathrm{~Hz}, 1 \mathrm{H}), 2.42$ (m, $1 \mathrm{H}), 2.30(\mathrm{~m}, 1 \mathrm{H}), 2.14(\mathrm{~s}, 1 \mathrm{H}), 2.01(\mathrm{~m}, 1 \mathrm{H}), 1.75(\mathrm{~m}, 3 \mathrm{H}), 1.50$ $(\mathrm{m}, 1 \mathrm{H}), 1.33(\mathrm{~m}, 1 \mathrm{H}), 1.23(\mathrm{~s}, 3 \mathrm{H}), 1.10(\mathrm{~m}, 1 \mathrm{H}), 0.78(\mathrm{~s}, 3 \mathrm{H})$.

${ }^{13} \mathrm{C}$ NMR (100 MHz, $\left.\mathrm{CD}_{3} \mathrm{OD}\right): \delta=172.5,148.2,143.1,136.1,129.4$, 121.2, 109.3, 80.9, 69.8, 64.3, 61.8, 54.8, 43.1, 38.7, 38.4, 36.7, 28.2, $23.1,22.8,16.0$.

ESI-MS: $m / z$ found for $\mathrm{C}_{20} \mathrm{H}_{28} \mathrm{O}_{4}: 333.20[\mathrm{M}+\mathrm{H}]^{+}$.

\section{Synthesis of And-4 and And-5}

A solution of 11,12-didehydro-14-deoxyandrographolide (0.86 g, 2 $\mathrm{mmol})$ in dichloromethane $(20 \mathrm{~mL})$ was added to a mixture of pyridinium chlorochromate $(0.87 \mathrm{~g}, 4 \mathrm{mmol})$ in dichloromethane $(7 \mathrm{~mL})$. The reaction temperature was programmed at $70{ }^{\circ} \mathrm{C}$ in a microwave synthesiser for 3 minutes to afford a mixture of 11,12-didehydro-19formyl-3-oxo-14-deoxyandrographolide (And-4) and 11,12-didehydro-19-formyl-14-deoxyandrographolide (And-5) with yields of $30 \%$ and $50 \%$, respectively.

\section{1,12-Didehydro-19-formyl-3-oxo-14-deoxyandrographolide} (And-4)

${ }^{1} \mathrm{H}$ NMR $\left(400 \mathrm{MHz}, \mathrm{CDCl}_{3}\right): \delta=9.69(\mathrm{~s}, 1 \mathrm{H}), 7.17(\mathrm{~m}, 1 \mathrm{H}), 6.91(\mathrm{~m}$, $1 \mathrm{H}), 6.11(\mathrm{~d}, J=16.0 \mathrm{~Hz}, 1 \mathrm{H}), 4.87(\mathrm{~m}, 1 \mathrm{H}), 4.79(\mathrm{~s}, 2 \mathrm{H}), 4.63(\mathrm{~m}$, $1 \mathrm{H}), 2.60(\mathrm{~m}, 2 \mathrm{H}), 2.41(\mathrm{~m}, 2 \mathrm{H}), 2.05(\mathrm{~m}, 2 \mathrm{H}), 1.86(\mathrm{~m}, 1 \mathrm{H}), 1.71(\mathrm{~m}$, $1 \mathrm{H}), 1.46(\mathrm{~m}, 1 \mathrm{H}), 1.27(\mathrm{~s}, 3 \mathrm{H}), 1.19(\mathrm{~m}, 1 \mathrm{H}), 1.00(\mathrm{~s}, 3 \mathrm{H})$.

${ }^{13} \mathrm{C}$ NMR $\left(100 \mathrm{MHz}, \mathrm{CDCl}_{3}\right): \delta=208.87,201.47,172.31,146.80$, 143.87, 135.09, 129.19, 122.16, 110.86, 69.82, 63.80, 60.10, 57.00, $39.54,39.23,37.16,36.44,24.26,17.17,14.29$.

ESI-MS: $m / z$ found for $\mathrm{C}_{20} \mathrm{H}_{26} \mathrm{O}_{4}: 331.18[\mathrm{M}+\mathrm{H}]^{+}$.

\section{1,12-Didehydro-19-formyl-14-deoxyandrographolide (And-5)}

${ }^{1} \mathrm{H}$ NMR $\left(400 \mathrm{MHz}, \mathrm{CDCl}_{3}\right): \delta=9.76(\mathrm{~s}, 1 \mathrm{H}), 7.15(\mathrm{~m}, 1 \mathrm{H}), 6.83(\mathrm{~m}$, $1 \mathrm{H}), 6.11(\mathrm{~d}, J=16.0 \mathrm{~Hz}, 1 \mathrm{H}), 4.78(\mathrm{~s}, 2 \mathrm{H}), 4.54(\mathrm{~m}, 1 \mathrm{H}), 4.07(\mathrm{~m}$, $1 \mathrm{H}), 3.48(\mathrm{~m}, 1 \mathrm{H}), 3.20(\mathrm{~m}, 1 \mathrm{H}), 2.53-1.54(\mathrm{~m}, 8 \mathrm{H}), 1.22(\mathrm{~s}, 3 \mathrm{H})$, $0.98(\mathrm{~m}, 1 \mathrm{H}), 0.75(\mathrm{~s}, 3 \mathrm{H})$.

${ }^{13} \mathrm{C}$ NMR $\left(101 \mathrm{MHz}, \mathrm{CDCl}_{3}\right): \delta=209.26,172.25,146.66,144.27$, 135.18, 129.12, 122.36, 111.08, 78.92, 69.80, 63.78, 60.12, 57.08, $39.85,39.22,37.17,36.39,24.25,17.21,14.32$.

ESI-MS: $m / z$ found for $\mathrm{C}_{20} \mathrm{H}_{24} \mathrm{O}_{4}: 329.17[\mathrm{M}+\mathrm{H}]^{+}$.

\section{Synthesis of And-6}

$\mathrm{NaOH}(0.1 \mathrm{~N}, 2.0 \mathrm{~mL})$ solution was added to a solution of And-1 (1.0 g) in acetone $(5 \mathrm{~mL})$. The reaction temperature was programmed at $120{ }^{\circ} \mathrm{C}$ in a microwave synthesiser for 2 minutes to afford the lactone ring-opened product And-6.

Yield: $85 \%$

${ }^{1} \mathrm{H}$ NMR $\left(\mathrm{CD}_{3} \mathrm{OD} 400 \mathrm{MHz}\right): \delta=6.72(\mathrm{t}, J=4.6 \mathrm{~Hz}, 1 \mathrm{H}), 5.67(\mathrm{~d}, J=$ $8.0 \mathrm{~Hz}, 1 \mathrm{H}$ ), 4.96 (d, J = 8.0 Hz, $1 \mathrm{H}$ ), 4.75 (br. s, $1 \mathrm{H}$ ), 4.68 (br. s, $1 \mathrm{H}$ ), 4.60 (br. s, $1 \mathrm{H}), 4.37(\mathrm{~m}, 1 \mathrm{H}), 4.12(\mathrm{~d}, J=10.2 \mathrm{~Hz}, 1 \mathrm{H}), 4.01(\mathrm{~d}, J=$ $10.8 \mathrm{~Hz}, 1 \mathrm{H}), 3.87$ (d, $J=12.0 \mathrm{~Hz}, 1 \mathrm{H}), 3.25(\mathrm{~m}, 1 \mathrm{H}), 2.50-1.20(\mathrm{~m}$, $10 \mathrm{H}), 1.10(\mathrm{~s}, 3 \mathrm{H}), 0.69(\mathrm{~s}, 3 \mathrm{H})$.

${ }^{13} \mathrm{C}$ NMR $\left(\mathrm{CD}_{3} \mathrm{OD}, 100 \mathrm{MHz}\right): \delta=170.80,148.57,146.25,131.86$, $108.10,77.91,66.54,65.85,63.87,55.48,53.37,43.02,38.75,37.16$, $36.07,27.63,24.55,22.90,20.95,15.04$.

ESI-MS: $m / z$ found for $\mathrm{C}_{20} \mathrm{H}_{32} \mathrm{O}_{6}: 369.21[\mathrm{M}+\mathrm{H}]^{+}$.

\section{Synthesis of Diacetonide(And-7)}

And-6 (900 mg, 1 equiv) was taken in acetone $(5 \mathrm{~mL}), p$-toluene sulfonic acid monohydrate ( $0.6 \mathrm{~g}, 0.3$ equiv) and 2,2-dimethoxy propane ( $3.8 \mathrm{~mL}, 3$ equiv) were added, and the mixture was heated in a microwave synthesiser for 3 minutes at $150{ }^{\circ} \mathrm{C}$. After completion of the reaction, triethylamine $(1 \mathrm{~mL})$ was added to quench the remaining catalyst and the solvents were removed in vacuo. The residue was subjected to column chromatography using hexane/EtOAc (8:2) as mobile phase to afford And-7.

Yield: $1.0 \mathrm{~g}$ (80\%); white crystalline solid; $\mathrm{mp} 202{ }^{\circ} \mathrm{C}$.

${ }^{1} \mathrm{H}$ NMR $\left(400 \mathrm{MHz}, \mathrm{CDCl}_{3}\right): \delta=6.70(\mathrm{t}, J=4.6 \mathrm{~Hz}, 1 \mathrm{H}), 5.65(\mathrm{~d}, J=$ $8.0 \mathrm{~Hz}, 1 \mathrm{H}$ ), 4.95 (d, J = $8.0 \mathrm{~Hz}, 1 \mathrm{H}$ ), 4.73 (br. s, $1 \mathrm{H}$ ), 4.70 (br. s, $1 \mathrm{H}$ ), 4.61 (br. s, $1 \mathrm{H}), 4.35(\mathrm{~m}, 1 \mathrm{H}), 4.17(\mathrm{~d}, J=10.2 \mathrm{~Hz}, 1 \mathrm{H}), 4.03(\mathrm{~d}, J=$ $10.8 \mathrm{~Hz}, 1 \mathrm{H}), 3.85$ (d, $J=12.0 \mathrm{~Hz}, 1 \mathrm{H}), 3.23(\mathrm{~m}, 1 \mathrm{H}), 2.49-1.22(\mathrm{~m}$, $10 \mathrm{H}), 1.09(\mathrm{~s}, 3 \mathrm{H}), 1.02(\mathrm{~m}, 6 \mathrm{H}), 0.93(\mathrm{~s}, 6 \mathrm{H}), 0.69(\mathrm{~s}, 3 \mathrm{H})$.

${ }^{13} \mathrm{C}$ NMR $\left(\mathrm{CDCl}_{3}, 100 \mathrm{MHz}\right): \delta=170.76,147.98,146.22,132.12$, 109.74, 109.73, 108.21, 78.02, 66.34, 65.89, 63.88, 55.53, 53.49, 43.04, $38.72,37.27,36.11,27.82,27.76,27.43,25.32,25.32,24.52,22.92$, 20.87, 16.27 .

ESI-MS: $m / z$ found for $\mathrm{C}_{26} \mathrm{H}_{40} \mathrm{O}_{6}: 449.59[\mathrm{M}+\mathrm{H}]^{+}$. 


\section{Synthesis of Amides And-8, And-9, and And-10}

To a solution of And-7 (100 mg, 1 equiv) in DMF, DCC (1.2 equiv) was added and the mixture was allowed to react for ca. 1 minute at r.t. in a microwave synthesiser. ${ }^{48}$ To this mixture, suitably substituted aromatic amine (1.2 equiv) was then added and the reaction mixture was allowed to react for 3 minutes. Progress of the reaction was monitored using TLC in EtOAc/hexane (30:70). After the completion of the reaction, the crude mixture was extracted with EtOAc $(3 \times 30 \mathrm{~mL})$ and the combined organic layers were then dried over sodium sulfate and purified through column chromatography to afford And-8, And-9 and And-10 in 85-90\% yield.

\section{And-8}

Yield: 85\%; white amorphous solid; $\mathrm{mp} 213^{\circ} \mathrm{C}$.

${ }^{1} \mathrm{H} \mathrm{NMR}\left(\mathrm{CDCl}_{3}, 400 \mathrm{MHz}\right): \delta=7.74(\mathrm{~m}, 2 \mathrm{H}), 7.53(\mathrm{~m}, 2 \mathrm{H}), 7.44(\mathrm{~m}$, $1 \mathrm{H}), 6.73(\mathrm{t}, J=4.5 \mathrm{~Hz}, 1 \mathrm{H}), 5.69(\mathrm{~d}, J=8.0 \mathrm{~Hz}, 1 \mathrm{H}), 4.98(\mathrm{~d}, J=8.0 \mathrm{~Hz}$, $1 \mathrm{H}$ ), 4.75 (br. s, $1 \mathrm{H}$ ), 4.71 (br. s, $1 \mathrm{H}$ ), 4.59 (br. s, $1 \mathrm{H}), 4.33$ (m, $1 \mathrm{H})$, $4.14(\mathrm{~d}, J=10.2 \mathrm{~Hz}, 1 \mathrm{H}), 4.05(\mathrm{~d}, J=10.8 \mathrm{~Hz}, 1 \mathrm{H}), 3.82(\mathrm{~d}, J=12.0 \mathrm{~Hz}$, $1 \mathrm{H}), 3.26(\mathrm{~m}, 1 \mathrm{H}), 2.50-1.20(\mathrm{~m}, 10 \mathrm{H}), 1.08(\mathrm{~s}, 3 \mathrm{H}), 1.01(\mathrm{~m}, 6 \mathrm{H})$, $0.92(\mathrm{~s}, 6 \mathrm{H}), 0.69(\mathrm{~s}, 3 \mathrm{H})$.

${ }^{13} \mathrm{C}$ NMR $\left(\mathrm{CDCl}_{3}, 100 \mathrm{MHz}\right): \delta=171.32,148.22,146.51,132.17$, $129.74,129.74,128.67,120.84,120.48,120.48,109.73,109.73$, $108.25,77.82,66.44,65.75,63.80,55.55,53.44,42.93,38.70,37.25$, $36.11,27.80,27.75,27.44,25.30,25.30,24.88,22.90,20.87,16.56$.

ESI-MS: $m / z$ found for $\mathrm{C}_{32} \mathrm{H}_{45} \mathrm{NO}_{5}: 524.34[\mathrm{M}+\mathrm{H}]^{+}$.

\section{And-9}

Yield: 90\%; white amorphous solid; $\mathrm{mp} 219^{\circ} \mathrm{C}$.

${ }^{1} \mathrm{H} \mathrm{NMR}\left(\mathrm{CDCl}_{3}, 400 \mathrm{MHz}\right): \delta=7.76(\mathrm{~d}, J=8 \mathrm{~Hz}, 1 \mathrm{H}), 7.43(\mathrm{~m}, 1 \mathrm{H})$, $7.11(\mathrm{~m}, 2 \mathrm{H}), 6.72(\mathrm{t}, J=4.5 \mathrm{~Hz}, 1 \mathrm{H}), 5.70(\mathrm{~d}, J=8.0 \mathrm{~Hz}, 1 \mathrm{H}), 4.98(\mathrm{~d}, J$ $=8.0 \mathrm{~Hz}, 1 \mathrm{H}$ ), 4.76 (br. s, $1 \mathrm{H}$ ), 4.71 (br. s, $1 \mathrm{H}$ ), 4.60 (br. s, $1 \mathrm{H}$ ), 4.32 $(\mathrm{m}, 1 \mathrm{H}), 4.14(\mathrm{~d}, J=10.2 \mathrm{~Hz}, 1 \mathrm{H}), 4.06(\mathrm{~d}, J=10.8 \mathrm{~Hz}, 1 \mathrm{H}), 3.83(\mathrm{~d}, J=$ $12.0 \mathrm{~Hz}, 1 \mathrm{H}), 3.63(\mathrm{~s}, 3 \mathrm{H}), 3.27(\mathrm{~m}, 1 \mathrm{H}), 2.50-1.20(\mathrm{~m}, 10 \mathrm{H}), 1.09(\mathrm{~s}$, $3 \mathrm{H}), 1.02(\mathrm{~m}, 6 \mathrm{H}), 0.94(\mathrm{~s}, 6 \mathrm{H}), 0.70(\mathrm{~s}, 3 \mathrm{H})$.

${ }^{13} \mathrm{C}$ NMR $\left(\mathrm{CDCl}_{3}, 100 \mathrm{MHz}\right): \delta=172.16,151.11,148.27,146.88$, 132.17, 126.31, 125.66, 121.33, 121.21, 112.19, 109.82, 109.81, $108.34,77.95,66.45,65.79,63.78,55.89,55.57,53.49,42.95,38.72$, $37.23,36.13,27.80,27.82,27.68,25.32,25.32,24.85,22.92,20.66$, 16.60 .

ESI-MS: $m / z$ found for $\mathrm{C}_{33} \mathrm{H}_{47} \mathrm{NO}_{6}: 554.34[\mathrm{M}+\mathrm{H}]^{+}$.

\section{And-10}

Yield: 90\%; white amorphous solid; $\mathrm{mp} 219^{\circ} \mathrm{C}$.

${ }^{1} \mathrm{H} \mathrm{NMR}\left(\mathrm{CDCl}_{3}, 400 \mathrm{MHz}\right): \delta=8.09(\mathrm{~d}, J=8.0 \mathrm{~Hz}, 1 \mathrm{H}), 7.81(\mathrm{t}, J=$ $8.0 \mathrm{~Hz}, 1 \mathrm{H}), 7.69(\mathrm{~m}, 2 \mathrm{H}), 6.72(\mathrm{t}, J=4.5 \mathrm{~Hz}, 1 \mathrm{H}), 5.67(\mathrm{~d}, J=8.0 \mathrm{~Hz}$, $1 \mathrm{H}$ ), 4.99 (d, $J=8.0 \mathrm{~Hz}, 1 \mathrm{H}), 4.78$ (br. s, $1 \mathrm{H}), 4.71$ (br. s, $1 \mathrm{H}$ ), 4.60 (br. s, $1 \mathrm{H}), 4.35(\mathrm{~m}, 1 \mathrm{H}), 4.15(\mathrm{~d}, J=10.3 \mathrm{~Hz}, 1 \mathrm{H}), 4.04(\mathrm{~d}, J=10.6 \mathrm{~Hz}$, $1 \mathrm{H}), 3.85(\mathrm{~d}, J=12.0 \mathrm{~Hz}, 1 \mathrm{H}), 3.25(\mathrm{~m}, 1 \mathrm{H}), 2.50-1.20(\mathrm{~m}, 10 \mathrm{H}), 1.09$ $(\mathrm{s}, 3 \mathrm{H}), 1.03(\mathrm{~m}, 6 \mathrm{H}), 0.92(\mathrm{~s}, 6 \mathrm{H}), 0.70(\mathrm{~s}, 3 \mathrm{H})$.

${ }^{13} \mathrm{C}$ NMR $\left(\mathrm{CDCl}_{3}, 100 \mathrm{MHz}\right): \delta=172.32,148.29,147.12,146.47$, $133.80,132.22,130.63,130.37,127.62,124.21,109.71,109.71$, 108.29, 77.83, 66.43, 65.89, 63.77, 55.49, 52.84, 43.16, 38.46, 37.52, 35.98, 27.56, 27.54, 27.48, 25.32, 25.32, 24.85, 22.92, 20.85, 16.77.

ESI-MS: $m / z$ found for $\mathrm{C}_{32} \mathrm{H}_{44} \mathrm{~N}_{2} \mathrm{O}_{7}: 569.31[\mathrm{M}+\mathrm{H}]^{+}$.

\section{Biology}

Sweet almond $\beta$-glucosidase and $p$-nitrophenyl $\beta$-D-glucopyranoside for glycosidase inhibition studies were purchased from Sigma. Phosphate buffer, ethanol, and DMSO were purchased from Sigma Chemicals Co. Glacial acetic acid from Fischer scientific, PBS and trichloroactetic acid (TCA) were from Merck specialties private limited.

\section{及-D-Glycosidase Inhibitory Assay}

All buffers and solutions were prepared using Millipore filtered water. Assays were performed in triplicate at $37{ }^{\circ} \mathrm{C}$ using 96 well microtitre plates with a final assay volume of $300 \mu \mathrm{L}$. All assays used $200 \mu \mathrm{L}$ of $250 \mu \mathrm{M} p$-nitrophenyl glycoside (substrate) solution, $50 \mu \mathrm{L}$ test inhibitor solution and $50 \mu \mathrm{L}$ enzyme solution $(0.2 \mathrm{U} / \mathrm{mL})$, buffered to $\mathrm{pH} 5.0$ in $0.12 \mathrm{M}$ phosphate (Pi) buffer. The liberated $p$-nitrophenol (PNP) was measured at $405 \mathrm{~nm}$ after quenching the reactions with $100 \mu \mathrm{L}$ borate buffer ( $\mathrm{pH} 9.8,0.2 \mathrm{M}$ ). Reaction mixture containing Pi buffer (pH 5.0) in place of inhibitory samples was used as negative control, and castanospermine (1,6,7,8-tetrahydroxyoctahydroindolizine), a commercially available $\beta$-D-glycosidase inhibitor, was included in the assay as positive control. The percentage inhibition was calculated using the following formula (Figure 2):

$$
\text { Inhibition }(\%)=1-\frac{\mathrm{ABS}_{\text {sample }}-\mathrm{ABS}_{\text {positive control }}}{\mathrm{ABS} \text { negative control }_{\text {n }}} \times 100
$$

Figure 2

For the time-scale inhibition studies, at each pre-incubation timestep, enzyme ( $50 \mu \mathrm{L}$ of $0.2 \mathrm{U} / \mathrm{mL}$ ) was added to the test inhibitor (50 $\mu \mathrm{L}$ of $1000 \mu \mathrm{M})$ or Pi buffer for the negative control $(50 \mu \mathrm{L})$. At the end of the pre-incubation time, the corresponding $p$-nitrophenyl glycopyranoside $(200 \mu \mathrm{L}$ of $250 \mu \mathrm{M})$ was added to each well and incubated for a further $5 \mathrm{~min}$ at $37^{\circ} \mathrm{C}$. To determine the inhibitory concentrations for the various inhibitors, enzyme $(50 \mu \mathrm{L}$ of $0.2 \mathrm{U} / \mathrm{mL})$ was added to each well containing $50 \mu \mathrm{L}$ of various concentrations of inhibitor $(0$, $100,250,500,1000,1500 \mu \mathrm{M}$; to give final assay concentrations of 0 , $16.6,41.5,83.3,166.7$, or $250.0 \mu \mathrm{M}$, respectively) and pre-incubated for $1 \mathrm{~h}$. After this time, the corresponding $p$-nitrophenyl glycopyranoside was added ( $200 \mu \mathrm{L}$ of $250 \mu \mathrm{M}$ ) and incubated for a further $5 \mathrm{~min}$. The results are expressed as percentage activity relative to the control wells. The $\mathrm{IC}_{50}$ values were determined using graph pad prism 5 software.

\section{Funding Information}

M.R. is grateful to MHRD for providing a research fellowship

\section{Acknowledgment}

We would like to thank Prof. Rakesh Sehgal, Director NIT (Srinagar) for the support of the research work.

\section{Supporting Information}

Supporting information for this article is available online at https://doi.org/10.1055/s-0036-1591967. 


\section{References}

(1) Dhiman, A.; Goyal, Ju.; Sharma, K.; Nanda, A.; Dhiman, S. J. Pharm. Sci. Innov. 2012, 1, 1.

(2) Puri, A.; Saxena, R.; Saxena, R. P.; Saxena, K. C.; Srivastava, V.; Tandon, J. S. J. Nat. Prod. 1993, 56, 995.

(3) Singha, P. K.; Roy, S.; Dey, S. Fitoterapia 2003, 74, 692.

(4) Shen, Y. C.; Chen, C. F.; Chiou, W. F. Br. J. Pharmacol. 2002, 135, 399.

(5) Zhang, C. Y.; Tan, B. K. Clin. Exp. Pharmacol. Physiol. 1996, 23, 675.

(6) Yu, B. C.; Hung, C. R.; Chen, W. C. Planta Med. 2003, 69, 1075.

(7) Borhanuddin, M.; Shamsuzzoha, M.; Hussain, A. H. Bangladesh Med. Res. Counc. Bull. 1994, 20, 24.

(8) Wang, D. W.; Zhao, H. Y. Chin. Med. J. (Engl.) 1994, 107, 464.

(9) Dua, V. K.; Ojha, V. P.; Roy, R. J. Ethnopharmacol. 2002, 95, 247.

(10) Calabrese, C.; Berman, S. H.; Babish, J. G. Phytother. Res. 2000, 14, 333.

(11) Amroyan, E.; Gabrielian, E.; Panossian, A. Phytomedicine 1999, 6 , 27.

(12) Choudhury, B. R.; Poddar, M. K. Methods Find Exp Clin Pharmacol. 1984, 6, 481.

(13) Handa, S. S.; Sharma, A. Indian J. Med. Res. 1990, 92, 284.

(14) Shukla, B.; Visen, P. K.; Patnaik, G. K.; Dhawan, B. N. Planta Med. 1992, 58, 146

(15) Kumar, R. A.; Sridevi, K.; Kumar, N. V. J. Ethnopharmacol. 2004, 92, 291.

(16) Rajagopal, S.; Kumar, R. A.; Deevi, D. S. J. Exp. Ther. Oncol. 2003, $3,147$.

(17) Chang, H. M. Volume 2; World Scientific Publishing Co. Ptd. Ltd., Singapore; 1987, p. 918.

(18) Shen, Y. C.; Chen, C. F.; Chiou, W. F. Planta Med. 2000, 66, 314.

(19) Shen, Y. C.; Chen, C. F.; Chiou, W. F. Br. J. Pharmacol. 2002, 135, 399.

(20) Iruretagoyena, M. I.; Sepulveda, S. E.; Lezana, J. P.; Hermoso, M.; Bronfman, M.; Gutierrez, M. A.; Jacobelli, S. H.; Kalergis, A. M. J. Pharmacol. Exp. Ther. 2006, 318, 59.

(21) Iruretagoyena, M. I.; Tobar, J. A.; Gonzalez, P. A.; Sepulveda, S. E.; Figueroa, C. A.; Burgos, R. A.; Hancke, J. L.; Kalergis, A. M. J. Pharmacol. Exp. Ther. 2005, 312, 366.

(22) Carretta, M. D.; Alarcon, P.; Jara, E.; Solis, L.; Hancke, J. L.; Concha, I. I.; Hidalgo, M. A.; Burgos, R. A. Eur. J. Pharmacol. 2009, $602,413$.

(23) Burgos, R. A.; Seguel, K.; Perez, M.; Meneses, A.; Ortega, M.; Guarda, M. I.; Loaiza, A.; Hancke, J. L. Planta Med. 2005, 71, 429.

(24) Pratheeshkumar, P.; Kuttan, G. J. Environ. Pathol. Toxicol. Oncol. 2011, 30, 33.
(25) Chen, J. H.; Hsiao, G.; Lee, A. R.; Wu, C. C.; Yen, M. H. Biochem. Pharmacol. 2004, 67, 1337.

(26) Yan, J.; Chen, Y.; He, C.; Yang, Z. Z.; Lu, C.; Chen, X. S. Cell Biol. Toxicol. 2012, 28, 47.

(27) Bernack, R. J.; Niedbala, M. J.; Korytnyk, W. Cancer Metastasis Rev. $1985,4,81$.

(28) Pili, R.; Chang, J.; Partis, R. A.; Mueller, R. A.; Chrest, F. J.; Passaniti, A. Cancer Res. 1995, 55, 2920.

(29) Humphries, M. J.; Matsumoto, K.; White, S. L.; Olden, K. Cancer Res. 1986, 46, 5215.

(30) Papandreou, M. J.; Barbouche, R.; Guieu, R.; Kieny, M. P.; Fenouillet, E. Mol. Pharmacol. 2002, 61, 186.

(31) Ouzounov, S.; Mehta, A.; Dwek, R. A.; Block, T. M.; Jordan, R. Antiviral Res. 2002, 55, 425.

(32) Schnidt, D. D.; Frommer, W.; Junge, B.; Muller, L.; Wingender, W.; Truschei, E.; Schafer, D. Naturwissenschaften 1977, 64, 535.

(33) Kameda, Y.; Asano, N.; Yoshikawa, M.; Takeucki, M.; Yamaguchi, T.; Matsui, K.; Horii, S.; Fukase, H. J. Antibiot. 1984, 37, 1301.

(34) Robinson, K. M.; Begovic, M. E.; Rhinehart, B. L.; Heineke, E. W.; Ducep, J. B.; Kastner, P. R.; Marshall, F. N.; Danzin, C. Diabetes 1991, 40, 825 .

(35) Fujisawa, T.; Ikegami, H.; Inoue, K.; Kawabata, Y.; Ogihara, T. Metabolism 2005, 54, 387.

(36) Van den Broek, L. A.; Kat-Van Den Nieuwenhof, M. W.; Butters, T. D.; Van Boeckel, C. A. J. Pharm. Pharmacol. 1996, 48, 172.

(37) Zhang, X. F.; Tan, B. K. Clin. Exp. Pharmacol. Physiol. 2000, 2, 358.

(38) Zhang, X. F.; Tan, B. K. Acta Pharmacol. Sin. 2000, 21, 1157.

(39) Rafidah, H.; Azimahtol, H. P.; Meenakshii, N. J. Ethnopharmacol. 2004, 95, 205.

(40) Siripong, P.; Kongkathip, B.; Preechanukool, K.; Picha, P.; Tunsuwan, K.; Taylor, W. C. J. Sci. Soc. Thailand 1992, 18, 187.

(41) Sambyal, V. S.; Goswami, K. N. Cryst. Res. Technol. 1995, 30, 629.

(42) Yong, J. K.; Akira, T.; Naoto, K.; Takeshi, K. Tetrahedron 1999, 55, 8353.

(43) Wu, C. Y.; Hsu, C. C.; Tsai, Y. C. Biochem. Biophys. Res. Commun. 2001, 284, 466.

(44) Verma, N.; Behera, B. C.; Sharma, B. O. Hacettepe J. Biol. Chem. 2012, 40, 7 .

(45) Ani, V.; Naidu, K. A. Eur. Food Res. Technol. 2008, 226, 897.

(46) Rupercht, R. M.; Mullaney, S.; Andersen, J.; Bronson, R. J. Acquired Immune Defic. Syndr. 1989, 2, 149.

(47) Shakeel-u-Rehman, ; Bhat, K. A.; Lone, S. H.; Malik, F. A. Arabian J. Chem. 2015, DOI: 10.1016/j.arabjc.2015.10.009.

(48) Ayoob, I.; Lone, S. H.; Masood-ur-Rahman, ; Zargar, O. A.; Bashir, R.; Shakeel-u-Rehman, ; Khuroo, M. A.; Bhat, K. A. ChemistrySelect 2017, 2, 10153. 